\section{Dryocosmus kuriphilus-induced Chestnut Galls and Their Inhabitants}

\author{
Michele R. Warmund ${ }^{1}$ \\ Division of Plant Sciences, University of Missouri, 1-31 Agriculture Building, \\ Department of Horticulture, Columbia, MO 65211
}

Additional index words. Asian chestnut gall wasp, Castanea mollissima, larval chambers, nutritive layer, Torymus sinensis

\begin{abstract}
Studies were conducted to characterize altered tissues of larvae-infested buds and stem and leaf galls induced by Dryocosmus kuriphilus Yasumatsu on Chinese chestnut trees (Castanea mollissima Blume) and to describe gall inhabitants. Bud and gall samples were collected from chestnut trees growing in Mantua, $\mathrm{OH}$, on 2 Mar. and 3 May 2012, respectively, and prepared for microscopy. Uni- and multilocular larval chambers containing one $D$. kuriphilus larva per chamber were observed in buds and stem galls. Evidence of insect-modified Castanea cells was present as a two-layer zone of hypertrophied plant cells adjacent to the larval chambers before budbreak on 2 Mar. By 3 May, stem and leaf galls were in the growth and differentiation stage of development. Within galls, torn cell walls and disorganized organelles were visible in the protoplasm of cells surrounding ovoid-shaped larval chambers. A continuous layer of nutritive cells with large nuclei and nucleoli, abundant lipid bodies and mitochondria, and fragmented vacuoles was contiguous to larval chambers. At the outermost region of the nutritive tissue, cells had recently divided. Larger vacuolated cells, with slightly thickened walls, were observed surrounding recently divided cells. Thin-walled parenchyma cells in the chestnut gall cortex had large vacuoles with fewer organelles than those of the nutritive layer. Vascular tissue within the gall was connected with that of the plant host tissue outside the gall. In some chestnut galls, a single parasitoid larva was found attached to a $D$. kuriphilus larva. Each parasitoid larva had six pairs of setae on its head capsule, a pair of clypeal setae, a notched labrum, a semicircular lobed labium, 13 post-cephalic body segments, and rows of long, erect setae on all body segments.
\end{abstract}

Dryocosmus kuriphilus is a cynipid wasp that adversely affects chestnut tree growth and nut production in Asia, Europe, and North America (Panzavolta et al., 2011; Payne et al., 1975; Tamura, 1960; Warmund, 2009). Adult female wasps oviposit in chestnut buds in early summer. Within 30 to $40 \mathrm{~d}$, larvae hatch and remain in buds until the next spring when buds begin to grow (Nakamura et al., 1964; Panzavolta et al., 2011). During winter, larvae are undetectable with the naked eye as a result of their small size and milky white coloration within chestnut buds with densely matted trichomes. After budbreak, D. kuriphilusinduced stem, petiole, and leaf galls (Fig. 1) are visible. These galls provide nutrients and shelter for the developing larvae as well as various parasitoids (Cooper and Rieske, 2011; Otake, 1980, 1989). In the fall, chestnut galls senesce and branch tips with galls die. Because of this dieback, floral primordia in these terminal branches do not produce chestnuts the next year.

Cynipid-induced galls typically have four stages of development: initiation, growth and differentiation, maturation, and dehiscence or gall opening (Rohfritsch, 1992). During gall

Received for publication 18 Mar. 2013. Accepted for publication 23 May 2013.

Contribution from the Missouri Agricultural Station project 322

${ }^{1}$ To whom reprint requests should be addressed; e-mailwarmundm@missouri.edu. hyperplasia and hypertrophy in response to larval feeding (Dreger-Juaffret and Shorthouse, 1992). A layer of nutritive tissue forms adjacent to the larval chamber and vascular tissue within the gall joins that of the host organ. During the maturation stage, the last larval instar consumes a large portion of cells in the nutritive layer. Sclerenchyma tissue also develops as a lignified sheath around the nutritive layer as larval feeding continues and the gall matures (Rohfritsch, 1992). The outermost layer of gall tissue (i.e., cortex) is composed of parenchyma cells and vascular tissues. By the final stage, the larva completes its development and gall growth ceases.

Anatomical features of some cynipidinduced galls have been studied, particularly those on Quercus, but variations in gall structure occur. For example, the number of cell layers varies among galls (Bronner, 1977). Also, nutritive tissue may be continuous around the larval chamber or present as isolated cell groupings projecting into the larval chamber (Bronner, 1981; Ross, 1932). Another variation occurs in Neuroterus quercusbaccaruminduced galls on Quercus leaves, where the lignified sheath is absent (Bronner, 1992). Because D. kuriphilus is difficult to detect in overwintering chestnut buds, little anatomical information about the larvae is available and cellular changes in their galls have not been examined. Therefore, this study was conducted to: 1 ) determine where $D$. kuriphilus larvae reside in dormant chestnut buds; 2) describe cellular alterations in chestnut tissues induced by $D$. kuriphilus larvae before and after budbreak; 3) identify key anatomical features of $D$. kuriphilus larvae inhabiting chestnut buds and galls; and 4) characterize a previously undescribed larval stage of a parasitoid attached to D. kuriphilus within galls.

\section{Materials and Methods} stalk. As the egg hatched, the larva turned toward the leaf surface and entered the cavity head first. Epidermal hairs formed on the gall surface, marking the point of egg attachment to the plant tissue.

In the growth and development phase, galls form and enlarge on the host plant by cellular
Scion wood was collected on 2 Mar. 2012 to examine buds on ten 12-year-old 'Qing' Chinese chestnut trees growing in a commercial orchard in Mantua, OH. Pesticides had never been applied to trees in this orchard. For light microscopy, 20 buds were placed in 
formalin-acetic acid-alcohol fixative. Later, tissue was dehydrated in tertiary butyl alcohol series and infiltrated and embedded in paraplast (Sass, 1958). Ten buds were then sectioned (10 $\mu \mathrm{m}$ thick) and stained with toluidine blue or safranin $\mathrm{O}$ for examination using a stereomicroscope (Leica M205 FA; Leica Microsystems, Wetzlar, Germany). Toluidine blue was used to discriminate cell types in sections (Ruzin, 1999). For safranin O-stained sections, a dark red color indicated highly lignified cells. Fifty each of galls on stems and leaves and non-galled stems and developing leaves were collected from the same trees and location on 3 May 2012. Ten 3- to 4-mm-diameter galls and eight each of non-galled stems and leaves were prepared for light microscopy as described previously.

For transmission electron microscopy, tissues from 10 galls were fixed in $2 \%$ glutaraldehyde and $2 \%$ paraformaldehyde in $0.1 \mathrm{M}$ sodium cacodylate buffer ( $\mathrm{pH}$ 7.35). Samples were then post-fixed in $1 \%$ osmium tetroxide in $0.1 \mathrm{M}$ sodium cacodylate buffer and dehydrated in a graded ethanol series, followed by acetone, and embedded in Spurr's resin. Sections were microtomed at $85 \mathrm{~nm}$, stained with Sato's triple lead stain (Sato, 1968) and 5\% aqueous uranyl acetate, and examined with a JEOL 1400 microscope (JEOL, Peabody, MA) operated at $80 \mathrm{kV}$.

After examining galls, D. kuriphilus larvae as well as smaller parasitoid larvae in contact with the former insect were removed from galls collected on 3 May. Twelve each of both types of larvae were fixed in $2 \%$ glutaraldehyde and $2 \%$ paraformaldehyde in $0.1 \mathrm{M}$ sodium cacodylate buffer ( $\mathrm{pH}$ 7.35). Samples were then transferred directly from fixative onto a scanning electron microscopy stub and examined at low vacuum at $2{ }^{\circ} \mathrm{C}$ with a FEI Quanta 600F Environmental microscope (North America NanoPort, Hillsboro, OR).

\section{Results and Discussion}

Longitudinal sections prepared from noninfested buds revealed a typical stem apex with surrounding leaf primordia (Fig. 2A). Vascular tissue was also visible within bud tissues. In D. kuriphilus-infested buds, larvae within their chambers were visible in leaf primordia (Fig. 2B). A two-layer zone of hypertrophied cells was located adjacent to a larval chamber. Surrounding this zone, recently divided cells were present. In contrast to earlier descriptions of plant tissue after cynipid wasp oviposition (Rohfritsch, 1971), a proliferation of epidermal hairs on the chestnut bud surface, indicating the site of egg attachment, was not evident. However, the presence of hypertrophied cells and cell division around larval chambers demonstrate that D. kuriphilusinduced alterations in chestnut tissue morphology occur before spring budbreak (Fig. 2C).

Transverse sections of non-galled chestnut stems had the typical tissue arrangement of dicotyledonous plants with the central pith, vascular cylinder, cortex, and epidermal cells with trichomes (Fig. 3) (Beck, 2005). Nongalled leaves had multicellular epidermal
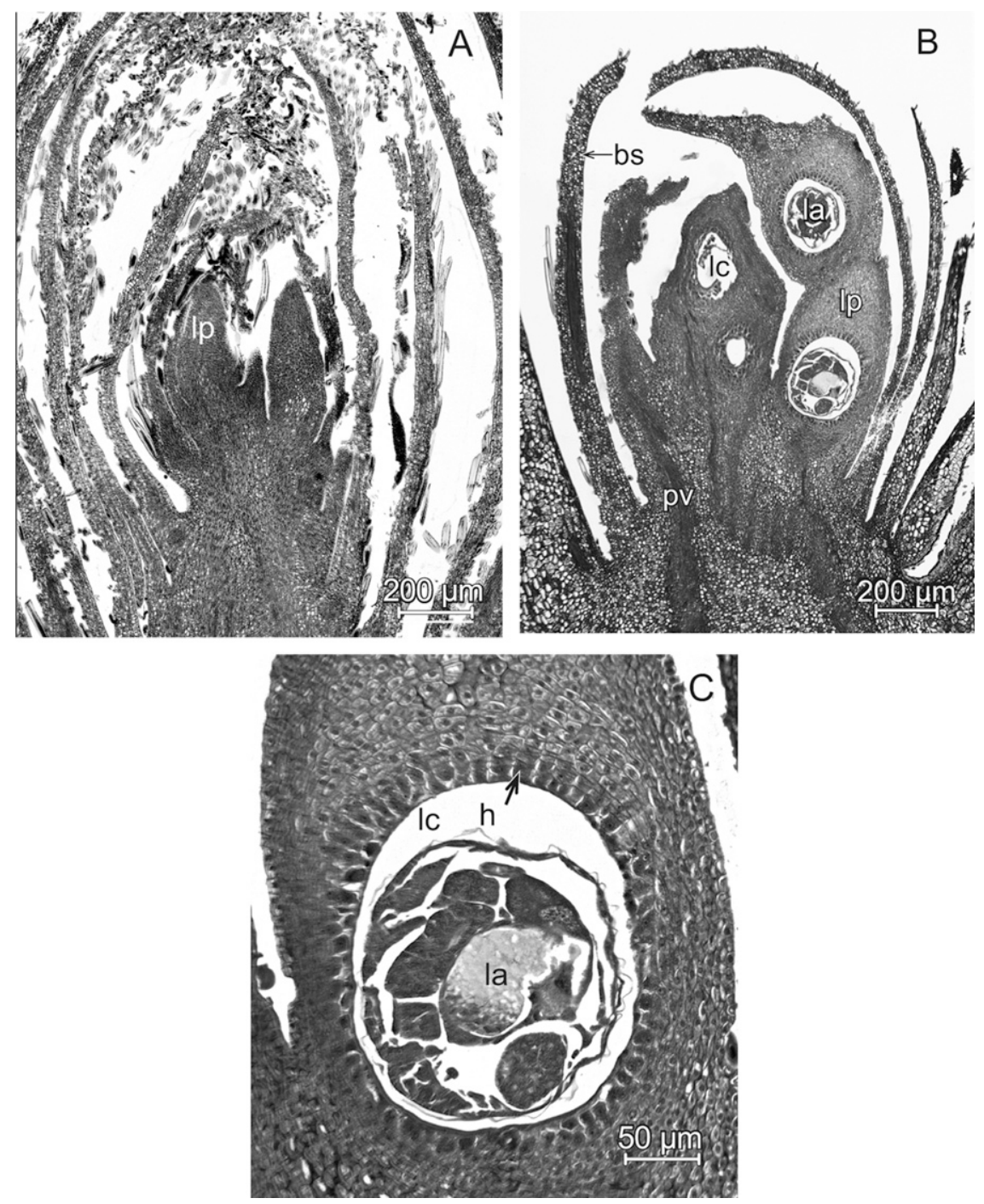

Fig. 2. Longitudinal sections of chestnut buds sampled on 2 Mar. from Mantua, OH. (A) Leaf primordia (lp) within a non-infested bud. (B) Four Dryocosmus kuriphilus larval chambers (lc) in developing leaves of chestnut buds. Larvae (la) are shown in two of the four chambers. Leaf primordia and darkly stained provascular (pv) tissue are visible within bud scales (bs) of chestnut buds. (C) Note the twolayer zone of hypertrophied cells $(\mathrm{h})$ adjacent to a chamber containing a larva and recently divided cells surrounding the zone of hypertrophied cells.

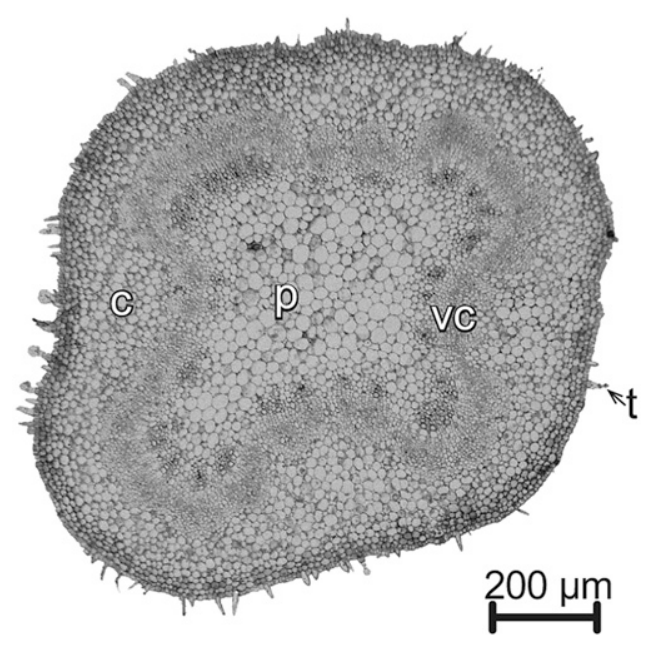

Fig. 3. Cross-section of a non-galled Chinese chestnut stem sampled on 3 May 2012. Note the pith (p), vascular cylinder (vc), cortex (c), and epidermal trichomes (t). 
trichomes and typical mesophyll cells in leaf blades and vascular tissues in the midvein (Fig. 4). Single and multilocular galls were present on chestnut stems and leaves with an ovoid-shaped chamber containing one larva (Fig. 5). This type of chambered structure, in which a larva is enclosed with plant tissue from the beginning of gall development, is a mark gall in Kuster's (1912) classification system.

Transverse sections of stem and leaf galls revealed similar tissues with multilayered cell types. Cells adjacent to the larval chamber exhibited damage, including sheared cell walls and disorganized protoplasm (Fig. 6). The destruction of these cells has been attributed to larval feeding and autolysis (Bronner, 1977; Duve and Wattiaux, 1966; Gahan and Maple, 1966). Cynipid larvae tear cell walls with their mandibles and imbibe cell contents by repetitive sucking movements with their pharynx and its muscular system. Mechanical slashing by the larvae or secretion of proteasic enzymes from larval salivary glands or malpighian tubules may also result in lysis of plant cells (Bronner, 1977; Roth, 1949).

Adjacent to the torn cells, a continuous, ovoid-shaped nutritive tissue was visible in D. kuriphilus-induced galls with multiple layers of cells (Fig. 7). Up to nine layers of cells were present near the distal position of the larval chamber and five layers of cells at the proximal part of the gall in cross-section. Large, intact nutritive cells had large nuclei and nucleoli (Fig. 8). Numerous lipid bodies, mitochondria, and fragmented vacuoles were present in nutritive cells. Like with other cynipid-induced galls, the nucleolus of some nutritive cells appeared vacuolated and organelles were often clustered near the nucleus (Rey, 1976; Rohfritsch, 1971). Bronner (1980) also indicated that cells with fragmented, small vacuoles, which are rich in acid hydrolases, represent transformation to nutritive cell function. Compared with other corresponding cells in non-galled plant tissue, nutritive cells in cynipid-induced galls have high concentrations of structural and enzymatic proteins, RNA, acid phosphatases, and glucose during gall development (Bronner, 1992).

Small, recently divided cells surrounded the nutritive layer in chestnut galls (Fig. 7). These cells likely enlarge with gall development. Larger vacuolated cells, with slightly thickened walls, were observed around recently divided cells. Thin-walled parenchyma cells in the chestnut gall cortex had large vacuoles with fewer organelles than those of the nutritive layer. Vascular cells were also visible throughout the parenchymatous cortex (Fig. 5). Few epidermal trichomes were present on the green- to red-pigmented gall surface. Based on these observations, including the absence of sclerenchyma tissue, galls sectioned in this study in early May were in the growth and differentiation stage of development.

At the mature stage of cynipid-induced gall development, inner tissues are composed of a nutritive cell layer and a lignified sheath of sclerenchyma cells. The outer gall tissues

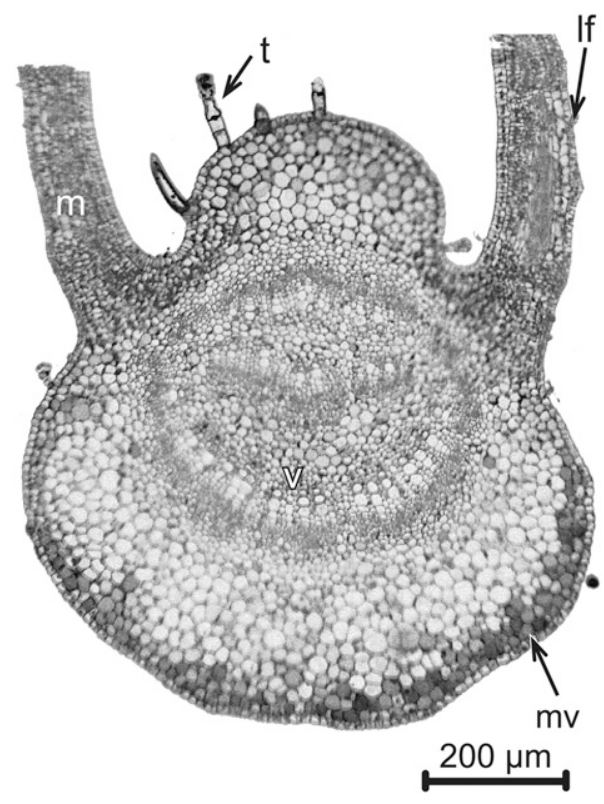

Fig. 4. Section of a non-galled midvein (mv) with attached portions of leaf (lf) blades. Note the vascular (v) tissue in the midvein and mesophyll (m) cells within the leaf blade.

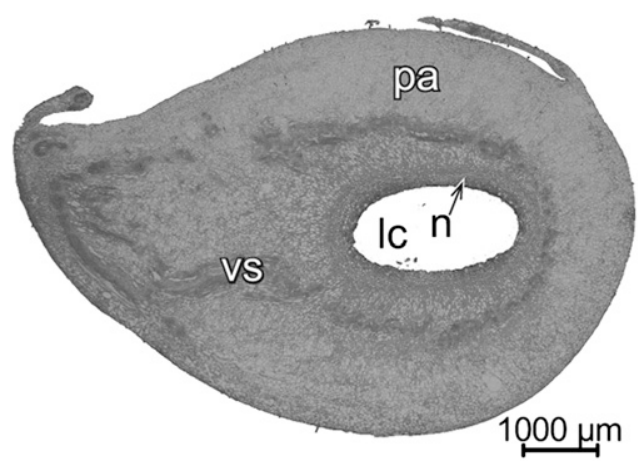

Fig. 5. Light micrograph of a cross-sectioned Chinese chestnut leaf gall on current season's growth sampled on 3 May 2012. Note the larval chamber (lc), nutritive (n) layer of cells, vascular system (vs), and parenchyma (pa) cells of the gall.

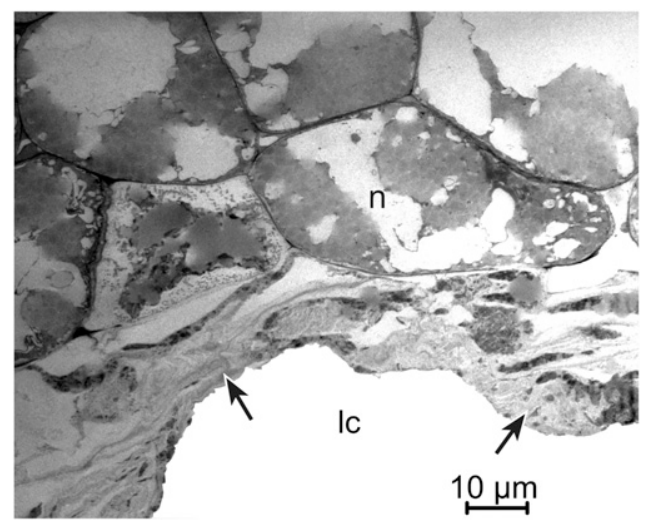

Fig. 6. Transmission electron micrograph of injured cells caused by Dryocosmus kuriphilus feeding Damaged cells (arrows) with disorganized organelles in the cytoplasm are present near the larval chamber (lc). A continuous nutritive (n) layer is contiguous to these cells.

include the cortex (i.e., parenchyma cells) and epidermis (Bronner, 1977). As a larva feeds on the innermost layer of nutritive cells, the adjacent cell layer develops the cytological characteristics of the inner layer. The mass of the inner gall is constant for each insect species, whereas that of the outer gall varies (Gaufillet and Fourcroy, 1966). Cooper and 
Rieske (2010) reported that the amount of sclerenchyma tissue was negatively correlated with the number of parasitoids inhabiting a gall. Another common feature of some mature cynipid-induced galls is the cytological gradient of compounds within the nutritive tissue (Bronner, 1992; Rey, 1976; Rohfritsch, 1974). Lipids and glucose are most highly concentrated in the nutritive cell layers nearest the larval chamber and progressively decrease outward. In contrast, in the outermost cells layers of the nutritive tissue (sometimes called the storage nutritive tissue), starch, amylase, and phosphorylase progressively increase outward (Bronner, 1992). In this study, starch grains were absent in the nutritive cells of galls, which may be attributed to their early stage of development, but may accumulate later.

By May, D. kuriphilus larvae, $\approx 2.3 \mathrm{~mm}$ long on average, were visible in galls (Fig. 9). Larvae were apodous and ventrally curved with smooth white cuticle. Twelve postcephalic segments were observed and the body was broadest around the middle and gradually tapered toward the posterior end. The head capsule was half the width of the prothorax and only the mouth parts were pigmented. On the head capsule, antennal areas were evident as well as a shallow longitudinal depression along the vertex that ended anteriorly at a poorly defined clypeus (Fig. 10). A recurved labrum with stout seta on either side of the midline was evident and mandibles were partially concealed by the labrum. Each maxilla also had a stout seta and the triangular labium had two stout subapical setae near the lateral margins.

Based on descriptions by Viggiani and Nugnes (2010), D. kuriphilus larvae imaged from galls in early May were terminal instars. First larval instars ( 0.2 to $0.6 \mathrm{~mm}$ long) were found in buds in summer through winter, second instars ( 0.8 to $1.5 \mathrm{~mm}$ long) occurred in galls in April to May, and terminal instars (2.3 $\mathrm{mm}$ long average) were present in galls from late April to late May in Italy (Viggiani and Nugnes, 2010). Mandible structure and the number (three to six pairs) and position of spiracles varied among the terminal instars.

In some gall chambers, a small $(\approx 810 \mu \mathrm{m}$ long) parasitoid larva was attached to a $D$. kuriphilus larva (Fig. 11). Each parasitoid larva had 13 visible post-cephalic segments and the head capsule was $\approx 60 \%$ of the width of the prothorax. There were numerous long setae on the head capsule and on each of the thoracic and abdominal segments. Antennae were evident as digitate protuberances and long post-vertical, vertical, parietal, frontal, genal, and supraoral setae were present on the head capsule (Fig. 12). Two clypeal setae, a notched labrum, and a semicircular labium were identified based on Toryminae terminal instar micrographs by Gomez et al. (2008) (Fig. 13). Labial folds appeared lobate with a small protuberance on each of six lobes.

The parasitoid removed from $D$. kuriphilus larvae is most likely Torymus sinensis Kamijo. In 1976, D. kuriphilus was released in Byron, $\mathrm{GA}$, and has become established in northern

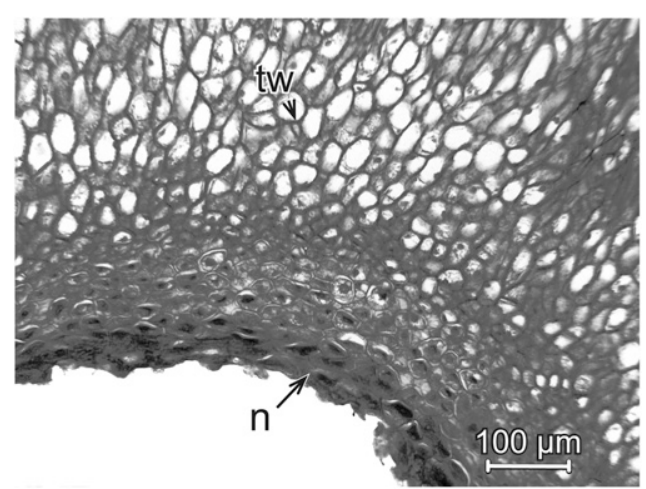

Fig. 7. Sheared cells adjacent to the larval chamber of a Dryocosmus kuriphilus-induced chestnut gall. Nutritive (n) cells generally have densely stained cytoplasm. Small, recently divided cells surround the nutritive layer in galls. Larger vacuolated cells, with slightly thickened walls (tw), were contiguous to small, recently divided cells.

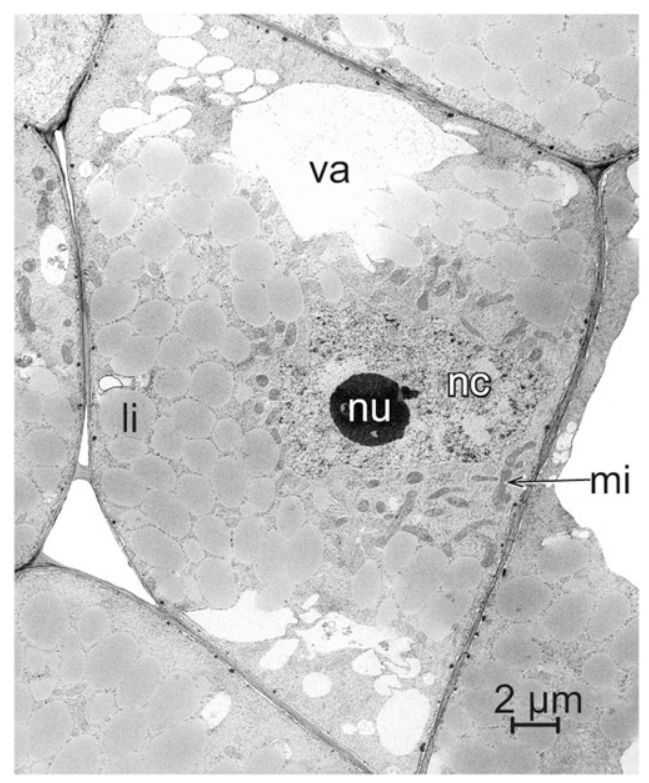

Fig. 8. A nutritive cell within a Chinese chestnut stem gall. Note the nucleolus (nu), hypertrophied nucleus (nc), fragmented vacuole (va), abundant lipid bodies (li), and mitochondria (mi).

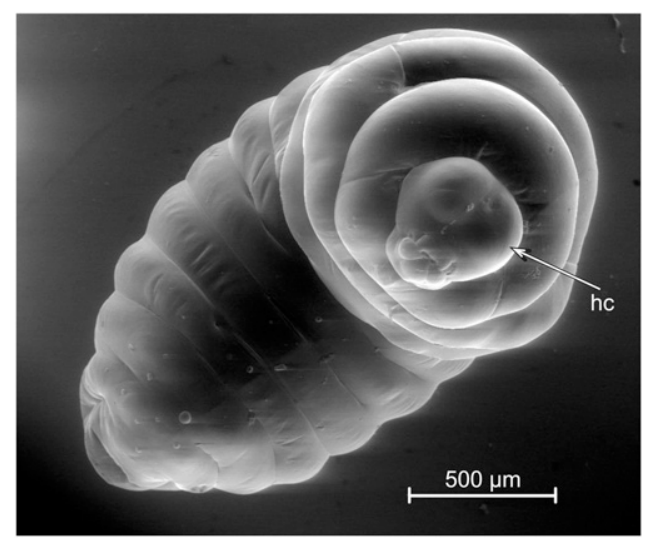

Fig. 9. Scanning electron micrograph of a terminal instar of Dryocosmus kuriphilus with the head capsule (hc) and 12 post-cephalic segments.

Ohio (Cooper and Rieske, 2011). Other unidentified native parasitoids have been associated with D. kuriphilus-induced galls in North America, but $T$. sinensis and Ormyrus labotus are the most frequently found parasitoids in chestnut orchards. Gomez et al. (2008) reported that larvae in the subfamily Toryminae are taxonomically separated from other 


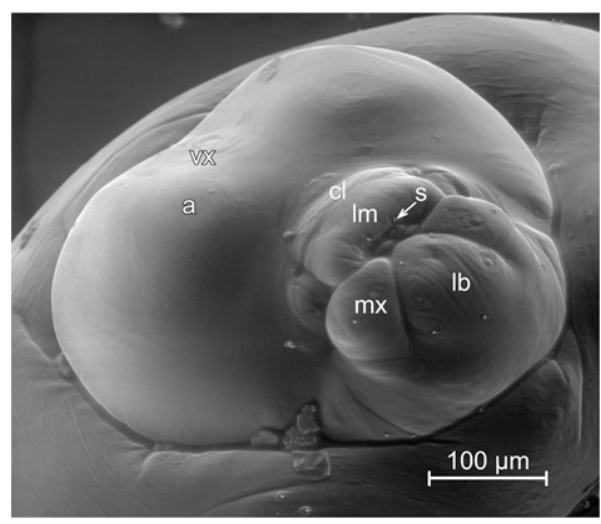

Fig. 10. Head capsule of a terminal instar of Dryocosmus kuriphilus with its antennal areas (a), vertex (vx), and clypeus (cl). Note the setae (s) on the labrum (lm), maxilla (mx), and on the labium (lb).

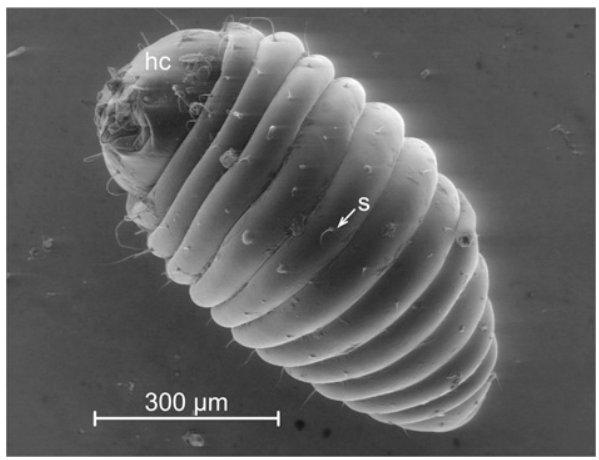

Fig. 11. Larval parasitoid found dorsally attached to a Dryocosmus kuriphilus larva inside a chestnut stem gall. Note the numerous long setae (s) on the head capsule (hc) and body segments.

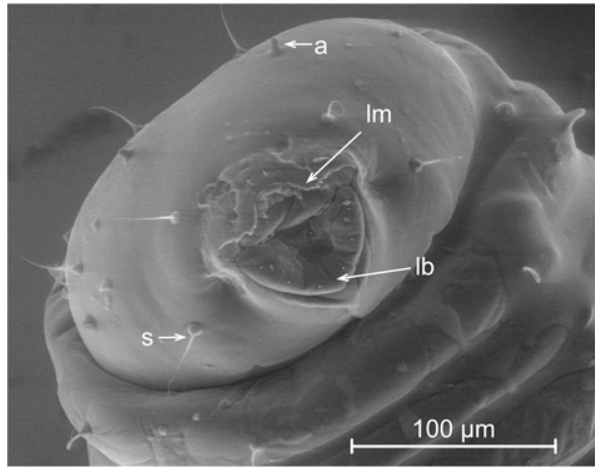

Fig. 12. Head capsule of a parasitoid removed from a Dryocosmus kuriphilus larva. Note the long setae (s), antennae (a), notched labrum (lm), and labium (lb).

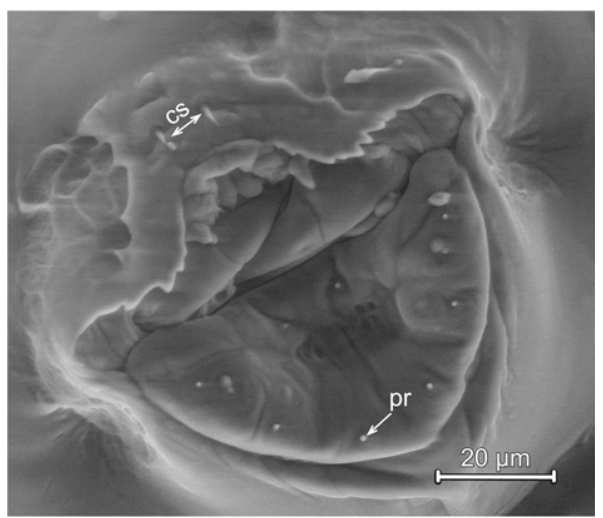

Fig. 13. A pair of clypeal setae (cs) and six protuberances (pr) on the labium of a parasitoid removed from a Dryocosmus kuriphilusty larva. closely related families by their many rows of long, erect setae on all body segments with setae as long as or longer than the length of one body segment. Also, several pairs of long setae are present on the head capsule of Toryminae terminal instars. In contrast, Ormyridae larvae have very short setae or lack setae on abdominal body segments. Thus, the parasitoid we imaged from D. kuriphilus-induced galls is probably not O. labotus, the second most frequently found parasitoid of the former larvae. Scanning electron micrographs of $T$. sinensis larvae apparently have not been published.

In conclusion, this study characterizes chestnut tissue alterations induced by a major pest, which ultimately results in arrested stem growth and a significant loss of nut yield. Before budbreak, minute $D$. kuriphilus larvae induce the formation of two layers of hypertrophied cells and cell division occurs around their larval chambers. After budbreak, galls form and serve as a nutritive sink. In young galls, larval activity results in damaged cells with disorganized protoplasm near the larval chamber. A nutritive layer surrounds the larval chamber and these cells contain numerous mitochondria and lipid bodies. Vacuolated parenchyma cells comprise the gall cortex as well as vascular tissues, which transport water and nutrients to other plant tissues. These galls not only provide food and shelter for D. kuriphilus larvae, but also offer protection for parasitoid larvae, including $T$. sinensis.

\section{Literature Cited}

Beck, C.B. 2005. An introduction to plant structure and development. Cambridge Univ. Press, Cambridge, UK

Bronner, R. 1977. Contribution a l'étude histochimique des tissus nourriciers des zoocécidies. Marcellia 40:1-134.

Bronner, R. 1980. Ultrastructural observations on lipid globules in nutritive cells of cynipid galls (Hymenoptera). Cecidology Intl. 1:127135.

Bronner, R. 1981. Observations on cynipid galls modified by inquilines larvae. Cecidology Intl. 2:53-61.

Bronner, R. 1992. The role of nutritive cells in the nutrition of cynipids and cecidomyiids, p. 118 140. In: Shorthouse, J.D. and O. Rohfritsch (eds.). Biology of insect-induced galls. Oxford Univ. Press, New York, NY.

Cooper, W.R. and L.K. Rieske. 2010. Gall structure affects ecological associations of Dryocosmus kuriphilus (Hymenoptera: Cynipidae). Environ. Entomol. 39:787-797.

Cooper W.R, Riesk L.K. 2011. A native and an introduced parasitoid utilize an exotic gallmaker host. BioControl 56:725-734.

Dreger-Juaffret, F. and J.D. Shorthouse. 1992. p. 8-33. In: Shorthouse, J.D. and O. Rohfritsch (eds.). Biology of insect-induced galls. Oxford Univ. Press, New York, NY.

Duve, C. and R. Wattiaux. 1966. Function of lysosomes. Annu. Rev. Physiol. 28:435-492.

Gahan, P.B. and A.J. Maple. 1966. The behavior of lysosome-like particles during cell differentiation. J. Expt. Bot. 17:151-155.

Gaufillet, C. and M. Fourcroy. 1966. Observations sur la galle d'Aulax glechomae L. sur Glechoma hederacea L. I. Structure et croissance. Marcellia 33:3-31. 
Gomez, J.F., J.L. Nieves-Aldrey, and M.H. Nieves. 2008. Comparative morphology, biology and phylogeny of terminal-instar larvae of the European species of Toryminae (Hym., Chalcidoidea, Torymidae) parasitoids of gall wasps (Hym. Cynipidae). Zool. J. Linn. Soc. 154:676-721.

Kuster, E. 1912. Die gallen der pflanzen: Ein lehrbuch fur botaniker und entomologen. Bot. Gaz. 53:72-74.

Nakamura, M., M. Kondo, Y. Ito, K. Miyashita, and K. Nakamura. 1964. Population dynamics of the chestnut gall wasp Dryocosmus kuriphilus Yasumatsu (Hymenoptera, Cynipidae). I. Description of the survey stations and the life histories of the gall wasp and its parasites. Jap. J. Appl. Entomol. Zool. 8:149-158.

Otake, A. 1980. Chestnut gall wasp, Dryocosmus kuriphilus Yasumatsu (Hymenoptera, Cynipidae): A preliminary study on trend of adult emergence and some other ecological aspects related to the final stage of its life-cycle. Appl. Entomol. Zool. (Jpn.) 15:96-105.

Otake, A. 1989. Chestnut gall wasp, Dryocosmus kuriphilus Yasumatsu (Hymenoptera, Cynipidae): Analyses of records on cell contents inside galls and emergence of wasps and parasitoids outside galls. Appl. Entomol. Zool. (Jpn.) 24:193-201.
Panzavolta, T., M. Bracalini, F. Croci, C. Campani, T. Bartoletti, G. Miniati, S. Benedettelli, and R. Tiberi. 2011. Asian chestnut gall wasp in Tuscan: Gall characteristics, egg distribution and chestnut cultivar susceptibility. Agr. For. Entomol. 14:139-145.

Payne, J.A., A.S. Menke, and P.M. Schroeder. 1975. Dryocosmus kuriphilus (Hymenoptera: Cynipidae): An Oriental chestnut gall wasp in North America. USDA Coop. Econ. Insect Rpt. 25:903-905.

Rey, L. 1976. Recherches comparées sur trois types d'hyménoptérocécidies (Cynipidae et Tenthrédinidae). Etude morphologique, histogique, et ultrastructurale du développement et de la différenciation. Essais expérimentaux Thése Doctorate es Sciences, Université de Nantes, Nantes, France.

Rohfritsch, O. 1971. Développement cécidien et role due parasite dans quelques galles d'arthropodes. Marcellia 37:233-339.

Rohfritsch, O. 1974. Infrastructure du tissue nourricier de la galle de l'Aulax glechomae L. sur Glechoma hederacea L. Protoplasma 81:205230.

Rohfritsch, O. 1992. Patterns in gall development, p. 60-86. In: Shorthouse, J.D. and O. Rohfritsch (eds.). Biology of insect-induced galls. Oxford Univ. Press, New York, NY.

Ross, H. 1932. A practical handbook on galls. Springer, Berlin, Germany.

Roth, P. 1949. Beiträge zur biologie der gallwespen. Verhandlungen des Naturforschenden Gesellschaft 60:104-178.

Ruzin, S.E. 1999. Plant microtechnique and microscopy. Oxford Univ. Press, New York, NY.

Sass, J.E. 1958. Botanical microtechnique. 3rd Ed. Iowa State Univ. Press, Ames, IA.

Sato, T. 1968. A modified method for lead staining of thin sections. J. Electron Microsc. (Tokyo) 17:158-159.

Tamura, M. 1960. Studies on the chestnut gall wasp, Dryocosmus kuriphilus Yasumatsu. (Part 1). Morphological observation on the growing process of the larva. J. Agr. Sci. 5:5-12.

Viggiani, G. and F. Nugnes. 2010. Description of the larval stages of Dryocosmus kuriphilus Yasumatsu (Hymenoptera: Cynipidae), with notes on their phenology. J. Entomol. Acarological Res. 42:39-45.

Warmund, M. 2009. Asian chestnut gall wasp. Univ. of Missouri Extension, Columbia, Missouri. 15 Oct. 2012. < http://extension.missouri $\mathrm{edu} / \mathrm{p} / \mathrm{PA} 100>$. 